\title{
Clinical and laboratory findings from patients with COVID-19 pneumonia in Babol North of Iran: a retrospective cohort study
}

\author{
MOSTAFA JAVANIAN ${ }^{1}$, MASOMEH BAYANI ${ }^{1}$, MEHRAN SHOKRI ${ }^{1}$, MAHMOUD SADEGHI-HADDAD-ZAVAREH ${ }^{1}$, \\ AREFEH BABAZADEH $^{1}$, BABAK YEGANEH ${ }^{1}$, SIMA MOHSENI $^{1}$, RAHELE MEHRAEEN $^{2}$, MAHDI SEPIDARKISH ${ }^{3}$, \\ ALI BIJANI $^{4}$, ALI ROSTAMI ${ }^{1}$, MEHDI SHAHBAZI ${ }^{5}$, AFROOZ MONADI TABARI $^{1}$, ASIEH SHABANI $^{6}$, \\ JILA MASROUR-ROUDSARI ${ }^{1}$, AMIR HOSSEIN HASANPOUR ${ }^{7}$, HOSSEIN EMAM GHOLINEJAD $^{7}$, \\ HOSSEIN GHORBANI ${ }^{8}$, SOHEIL EBRAHIMPOUR ${ }^{1}$ \\ ${ }^{1}$ Infectious Diseases and Tropical Medicine Research Center, Health Research Institute, \\ Babol University of Medical Sciences, Babol, I.R. Iran \\ ${ }^{2}$ Department of Radiology, Rouhani Hospital, Babol University of Medical Sciences, Babol, Iran \\ ${ }^{3}$ Department of Biostatistics and Epidemiology, Babol University of Medical Sciences, Babol, Iran \\ ${ }^{4}$ Social Departments of Health Research Center, Health Research Institute, Babol University of Medical Sciences, Babol, I.R. Iran \\ ${ }^{5}$ Cellular and Molecular Biology Research Center, Health Research Institute, Babol University of Medical Sciences, Babol, Iran \\ ${ }^{6}$ Clinical Research Development Unite of Rouhani Hospital, Babol University of Medical Sciences, Babol, I.R. Iran \\ ${ }^{7}$ Student Research Committee, Babol University of Medical Sciences, Babol, Iran \\ ${ }^{8}$ Department of Pathology, Rouhani Hospital, Babol University of Medical Sciences, Babol, Iran
}

\begin{abstract}
Background. In December 2019, China has experienced an outbreak of novel coronavirus disease 2019 (COVID-19). Coronavirus has now spread to all of the continents. We aimed to consider clinical characteristics, laboratory data of COVID-19 that provided more information for the research of this novel virus.

Methods. We performed a retrospective cohort study on the clinical symptoms and laboratory findings of a series of the 100 confirmed patients with COVID-19. These patients were admitted to the hospitals affiliated to Babol University of Medical Sciences (Ayatollah Rohani, Shahid Beheshti and Yahyanejad hospitals) form 25 February 2020 to 12 March 2020.

Results. Nineteen patients died during hospitalization and 81 were discharged. Non-survivor patients had a significantly higher C-reactive protein (CRP) (MD: 46.37, 95\% CI: 20.84, 71.90; $\mathrm{P}=0.001$ ), white blood cells (WBCs) (MD: 3.10, 95\% CI: 1.53, 4.67; $\mathrm{P}<0.001$ ) and lower lymphocyte (MD: $-8.75,95 \%$ CI: $-12.62,-4.87 ; \mathrm{P}<0.001)$ compared to survivor patients Data analysis showed that comorbid conditions (aRR: $2.99,95 \% \mathrm{CI}: 1.09,8.21, \mathrm{P}=0.034$ ), higher CRP levels (aRR: 1.02 , $95 \%$ CI: $1.01,1.03, \mathrm{P}=0.044)$, and lower lymphocyte (aRR: $0.82,95 \% \mathrm{CI}: 0.73,0.93, \mathrm{P}=0.003$ ) were associated with increased risk of death.

Conclusions. Based on our findings, most non-survivors are elderly with comorbidities. Lymphopenia and increased levels of WBCs along with elevated CRP were associated with increased risk of death. Therefore, it is best to be regularly assessed these markers during treatment of COVID19 patients.
\end{abstract}

Key words: COVID-19, pneumonia, elderly, lymphopenia, leukocyte count, C-reactive protein, mortality.

\section{INTRODUCTION}

At the end of 2019, an acute respiratory pneumonia known as novel coronavirus infection (COVID-19) has emerged in China and rapidly spread from China to other countries [1,2]. As of March 23, 2020, the majority of world countries (about 190 countries) were faced with the disease and at least 332,930 confirmed cases and 14,510 deaths were reported by COVID-19 worldwide [3]. To this date, Iran is ranked $6^{\text {th }}$ country for both morbidity and mortality rate. Up to March 21 , the number of confirmed cases in Iran has been raised to 19,664 and 1,433 death was reported. Babol in the north of Iran was one of the first cities with confirmed cases. Babol has a population of about 530,000 which, due to the availability of appropriate hospitals and academic facilities, covers over 100,000 people of the surrounding towns for treatment during times of crisis. Despite the large outbreak over the world, the clinical symptoms and laboratory inspection of COVID-19 is largely unknown [4]. There are many symptoms of influenza, common cold, and COVID-19 that are similar, and it can be problematic to discrimination [5]. Moreover, the clinical features of severe COVID-19 patients were similar to the Middle East respiratory syndromerelated coronavirus (MERS-CoV) and severe acute 
respiratory syndrome coronavirus (SARS-CoV) that might occur acute respiratory distress syndrome (ARDS), acute cardiac injury, acute liver and kidney injury and even death $[6,7]$. There are no vaccines and no FDA-approved therapeutics or drugs to treat, cure or prevent COVID-19 and this issue is more important in the case of Iran, because Iran is under severe sanctions [8-10]. Despite the growing body of studies in the recent four months, there are few reports on the clinical and laboratory features of COVID-19 cases outside China, and especially in Iran. In this descriptive study we aimed to analysis the epidemiologic aspects, clinical symptoms and laboratory findings, and outcomes of the 100 patients with confirmed COVID-19 in Babol, Mazandaran province, north of Iran.

\section{MATERIALS AND METHODS}

We carried out a retrospective cohort analysis on the clinical symptoms and laboratory findings of a series of 100 confirmed adult patients ( $\geq 18$ years old) with COVID-19. Patients were admitted to the hospitals affiliated to Babol University of Medical Sciences (Ayatollah Rohani, Shahid Beheshti and Yahyanejad hospitals) from 25 February 2020 to 12 March 2020 with final follow-up for the study on 17 March 2020. Our treatment center covers more than 1 million people living in Mazandaran province, North of Iran. To extract the clinical and laboratory data, the hospital medical records of patients were analyzed by a well-trained research team of the infectious diseases and tropical medicine research center, Babol University of medical sciences, Iran.

The following data were extracted from each medical record: epidemiological, demographic, clinical, laboratory, treatment, and outcome data. All parts of this study were approved by the Research Ethics Committee of the Babol University of Medical Science, Babol, Iran (no. IR.MUBABOL.HRI.REC. 1398.350). All the enrolled patients were informed about the study. We only included physician- and laboratory-confirmed (Reverse transcription polymerase chain reaction (RT-PCR) positive) cases and suspected cases with similar clinical symptoms were excluded from this study. In other words, all adult cases who were diagnosed with COVID-19 according to the WHO interim guidance were screened, and those who were discharged or died between 25 February 2020 to 12 March 2020, were included in our study [3]. Explain further, all adults with lymphopenia (lymphocyte count $<1.0 \times 10^{9} / \mathrm{L}$ ) and CRP elevations greater than 30 with shortness of breath and blood oxygen saturation $<93 \%$ were entered the study. All the recovered patients with COVID-19 had completely resolved signs and symptoms, had significant improvement in pulmonary (blood oxygen saturation $\geq 93 \%$ ) and extrapulmonary organ dysfunction, and no longer needed supportive care before hospital discharge.

Methods for physician- and laboratory confirmation of COVID-19 infection have been described using the same protocols previously [11]. For example RT-PCR assessed for nasal and pharyngeal swab specimens. Also, routine blood examinations were complete blood count, coagulation profile, serum biochemical tests.

\section{Statistical analysis}

We present continuous variables as mean (SD) if they are normally distributed or median (IQR) if they are not, and categorical variables as count (\%). Baseline demographic and clinical characteristics were compared among the survivor and non-survivor patients by using the independent sample t-test for continuous data and a chi-square test for categorical data. The association between these characteristics and in-hospital death was determined using univariable and multivariable modified Poisson regression. Considering the low amount of in-hospital death and to avoid overfitting in the model, only five variables (age, previous underlying diseases, comorbid conditions, CRP, Lymphocyte and WBC) were chosen for multivariable analysis. The magnitude of the effect is presented as adjusted RR and its $95 \%$ confidence interval. A two-sided $\alpha$ of less than 0.05 was considered statistically significant. All statistical analyses were performed with Stata 13.0 (Stata Corp LP, College Station, Texas, USA).

\section{RESULTS}

One hundred ten adult patients were hospitalized in three state hospitals with COVID-19 before 12 March 2020. One patient with a suspected diagnosis and nine inpatients without available key data in their medical records excluded. We included 100 inpatients in the final analysis. Nineteen patients died during hospitalization and 81 were discharged. The demographic and clinical characteristics are shown in Table 1. All of the 100 enrolled cases showed bilateral involvement of chest CT scans.

The mean age of the patients was 60.12 years (median: 59, IQR: 21), ranging from 18 years to 93 years, and nearly half of the patients were female. 
Half of the patients $(50 \%)$ had comorbidities with diabetes (34\%) being the most common comorbidity, followed by hypertension $(31 \%)$, coronary heart disease $(22 \%)$ and Chronic kidney disease $(11 \%)$. The mean interval between illness onset (hospitalization) to discharge was 7.01 (95\% CI: $6.25,7.77)$ days (median: 6, IQR: 6), ranging from one day to 17 days. Anorexia (86\%, 95\% CI: 77.62, 92.12) was the most frequently observed symptoms, followed by dry cough $(82 \%, 95 \%$ CI: $73.05,88.96)$, dyspnea
(82\%, 95\% CI: $73.05,88.96)$, fever (77\%, 95\% CI: $67.51,84.82)$ and fatigue $(77 \%, 95 \%$ CI: 67.51 , $84.82)$. Frothy three patients required mechanical ventilation, of whom 19 (44.18\%, 95\% CI: 29.07, $60.12)$ died. Acute cardiac injury $(32.55 \%, 95 \% \mathrm{CI}$ : $19.07,48.54$ ) has been the most frequently observed complication, followed by ventilator-associated pneumonia (30.23\%, 95\% CI: 17.18, 48.54), ARDS (9.30\%, 95\% CI: $2.59,2.21)$ and arrhythmia $(4.65 \%$, 95\% CI: 0.56, 15.81) (Table 1).

Table 1

Baseline characteristics of patients infected with COVID-19

\begin{tabular}{|c|c|c|c|c|}
\hline & $\begin{array}{l}\text { All patients } \\
(\mathrm{n}=100)\end{array}$ & $\begin{array}{c}\text { Deceased patients } \\
(n=19)\end{array}$ & $\begin{array}{c}\text { Survivor patients } \\
(\mathrm{n}=\mathbf{8 1})\end{array}$ & P-value * \\
\hline Age, mean (SD), y & $60.12(13.87)$ & $69.26(11.10)$ & $57.74(13.58)$ & 0.001 \\
\hline \multicolumn{5}{|l|}{ Sex } \\
\hline Male & $51(51)$ & $12(57.1)$ & $39(49.4)$ & \multirow{2}{*}{0.526} \\
\hline Female & $49(49)$ & $9(42.9)$ & $40(50.6)$ & \\
\hline \multicolumn{5}{|l|}{ Coexisting conditions } \\
\hline Hypertension & $32(32)$ & $12(63.15)$ & $20(24.69)$ & 0.001 \\
\hline Diabetes & $37(37)$ & $10(52.63)$ & $27(33.33)$ & 0.116 \\
\hline Malignancy & $4(4)$ & $3(15.78)$ & $1(1.23)$ & 0.684 \\
\hline Cardiovascular disease & $20(20)$ & $8(42.10)$ & $12(14.81)$ & 0.003 \\
\hline Chronic kidney disease & $12(12)$ & $5(26.31)$ & $7(8.64)$ & 0.032 \\
\hline Liver disease & $3(3)$ & $2(10.52)$ & $1(1.23)$ & 0.829 \\
\hline $\begin{array}{l}\text { Cerebrovascular } \\
\text { disease }\end{array}$ & $3(3)$ & $2(10.52)$ & $1(1.23)$ & 0.829 \\
\hline COPD & $12(12)$ & $5(26.31)$ & $7(8.64)$ & 0.032 \\
\hline \multicolumn{5}{|l|}{ Signs and symptoms } \\
\hline Fever & $77(77)$ & $15(78.94)$ & $62(76.54)$ & 0.823 \\
\hline Fatigue & $77(77)$ & $15(78.94)$ & $62(76.54)$ & 0.823 \\
\hline Dry cough & $82(82)$ & $16(84.21)$ & $66(81.48)$ & 0.780 \\
\hline Anorexia & $86(86)$ & $18(94.73)$ & $68(83.95)$ & 0.223 \\
\hline Myalgia & $50(50)$ & $9(47.36)$ & $41(50.61)$ & 0.798 \\
\hline Dyspnea & $82(82)$ & $16(84.21)$ & $66(81.48)$ & 0.780 \\
\hline Expectoration & $45(45)$ & $7(36.84)$ & $38(46.91)$ & 0.427 \\
\hline Pharyngalgia & $26(26)$ & $3(15.78)$ & $23(28.39)$ & 0.259 \\
\hline Diarrhea & $14(14)$ & $2(10.52)$ & $12(14.81)$ & 0.627 \\
\hline Constipation & $16(16)$ & $7(36.84)$ & $9(11.11)$ & 0.005 \\
\hline Haemoptysis & $7(7)$ & $1(5.26)$ & $6(7.40)$ & 0.067 \\
\hline Dizziness & $41(41)$ & $10(52.63)$ & $31(38.27)$ & 0.252 \\
\hline Headache & $59(59)$ & $9(47.36)$ & $50(61.72)$ & 0.897 \\
\hline Vomiting & $45(45)$ & $11(57.89)$ & $34(41.97)$ & 0.209 \\
\hline Abdominal pain & $19(19)$ & $3(15.78)$ & $16(19.75)$ & 0.691 \\
\hline Chest pain & $43(43)$ & $12(63.15)$ & $31(38.27)$ & 0.048 \\
\hline $\begin{array}{l}\text { Hospital admission } \\
\text { median (IQR), d }\end{array}$ & $6(6)$ & $5(6)$ & $6(6)$ & 0.514 \\
\hline $\begin{array}{l}\text { Heart rate, median (range), } \\
\text { bpm }\end{array}$ & $80(70-100)$ & $80(74-90)$ & $80(70-100)$ & 0.769 \\
\hline $\begin{array}{l}\text { Respiratory rate, median } \\
\text { (range) }\end{array}$ & $20(18-24)$ & $20(18-20)$ & $20(18-24)$ & 0.199 \\
\hline $\begin{array}{l}\text { Mean arterial pressure, } \\
\text { median (range), } \mathrm{mm} \mathrm{Hg}\end{array}$ & $\begin{array}{c}120.60(90.60- \\
160.90)\end{array}$ & $125.80(100.60-160.90)$ & $110.70(90.60-150.90)$ & 0.005 \\
\hline \multicolumn{5}{|l|}{ Outcome } \\
\hline ARDS & $4(4)$ & $3(15.78)$ & $1(1.23)$ & 0.003 \\
\hline Acute cardiac injury & $14(14)$ & $6(31.57)$ & $8(9.87)$ & 0.014 \\
\hline Arrhythmia & $2(2)$ & $1(5.26)$ & $1(1.23)$ & 0.258 \\
\hline $\begin{array}{l}\text { Ventilator-associated } \\
\text { pneumonia }\end{array}$ & $13(13)$ & $6(31.57)$ & $7(8.64)$ & 0.007 \\
\hline
\end{tabular}


Compared with survivor patients $(\mathrm{n}=81)$, non-survivors $(\mathrm{n}=19)$ were significantly older (MD: 11.52 , 95\% CI: 4.80, 18.24; $\mathrm{P}<0.001)$ and were more likely to have underlying diseases, including hypertension (RR: 2.55, 95\% CI: 1.53, 4.27; $\mathrm{P}=0.001$ ), cardiovascular disease (RR: $3.19,95 \%$ CI: $1.51,6.72 ; \mathrm{P}=0.003)$, chronic kidney disease (RR: 3.04, 95\% CI: 1.08, 8.55; P = 0.032), and chronic obstructive pulmonary disease (COPD) (RR: 3.04, 95\% CI: $1.08,8.55 ; \mathrm{P}=0.032)$. The occurrence of ARDS (3 [15.75\%] vs $1[1.23 \%], \mathrm{P}=0.003)$, Acute cardiac injury (6 [31.57\%] vs $8[9.87 \%], \mathrm{P}=0.014)$ and ventilator-associated pneumonia (6 [31.57\%] vs $7[8.64 \%], \mathrm{P}=0.007$ ) was higher compared to survivor patients. Non-survivor patients had a significantly higher CRP (MD: 46.37, 95\% CI: 20.84, 71.90; $\mathrm{P}=0.001$ ), WBCs (MD: $3.10,95 \%$ CI: $1.53,4.67 ; \mathrm{P}<0.001)$ and lower lymphocyte (MD: $-8.75,95 \%$ CI: $-12.62,-4.87 ; \mathrm{P}<0.001$ ) compared to survivor patients (Table 2).

Table 2

Laboratory findings of patients infected with COVID-19 on admission to hospital

\begin{tabular}{|l|c|c|c|c|}
\hline & $\begin{array}{c}\text { All patients } \\
(\mathbf{n}=\mathbf{1 0 0})\end{array}$ & $\begin{array}{c}\text { Deceased patients } \\
(\mathbf{n = 1 9 )}\end{array}$ & $\begin{array}{c}\text { Survivor patients } \\
(\mathbf{n}=\mathbf{8 1})\end{array}$ & P-value $^{*}$ \\
\hline White blood cell count, $\times 10^{9} / \mathrm{L}$ & $5.70(2.30-16.40)$ & $8.30(3-15.90)$ & $5.30(2.30-16.40)$ & $<0.001$ \\
\hline Lymphocyte count, $\times 10^{9} / \mathrm{L}$ & $2.40(0.14-4.01)$ & $1.45(0.8-3.10)$ & $2.60(0.14-4.01)$ & $<0.001$ \\
\hline Eosinophils count, $\times 10^{9} / \mathrm{L}$ & $3(1-10)$ & $2.50(1-10)$ & $3(1-8)$ & 0.598 \\
\hline Platelet count, $\times 10^{9} / \mathrm{L}$ & $186(90-436)$ & $210(90-421)$ & $183.5(90-436)$ & 0.062 \\
\hline Creatinine, $\mu \mathrm{mol} / \mathrm{L}$ & $100(60-530)$ & $110(70-380)$ & $100(60-530)$ & 0.102 \\
\hline C-reactive protein $(\mathrm{mg} / \mathrm{L})$ & $52(1.9-243)$ & $92(12-243)$ & $47.15(1.9-174)$ & 0.001 \\
\hline Haemoglobin $(\mathrm{g} / \mathrm{L})$ & $12.2(6.1-16)$ & $12.15(9.5-14.6)$ & $12.20(6.1-16)$ & 0.761 \\
\hline Potassium $(\mathrm{mmol} / \mathrm{L})$ & $4.17(3.4-5.2)$ & $4.20(3.7-5)$ & $4.10(3.4-5.2)$ & 0.121 \\
\hline Sodium $(\mathrm{mmol} / \mathrm{L})$ & $135(117-145)$ & $133(117-145)$ & $135(128-145)$ & 0.001 \\
\hline
\end{tabular}

The area under the ROC curve for CRP levels as a predictor of in-hospital death was $70.70(95 \%$ CI: $56.50,84.89)$. A CRP level of $>64.8 \mathrm{mg} / \mathrm{dl}$ associated with in-hospital death, with a sensitivity of $70.05 \%$ (95\% CI: $60.01,78.75)$, the specificity was $70.59 \%$ (95\% CI: $62.10,79.89)$, the positive LR was 2.38 , and the negative LR was 0.42 . A WBC of $>6.9$ count $\times 10^{9} / \mathrm{L}$ (AUC: $74.68,95 \%$ CI: 61.79 , 87.57) and a lymphocyte of $>1.7$ count $\times 10^{9} / \mathrm{L}$ (AUC: 79.71, 95\% CI: 69.04, 90.37) were associated with infection, with a sensitivity of $73.68 \%$ and $84.62 \%$, and a specificity of $67.09 \%$ and $65.0 \%$, respectively (Figure 1). We found that comorbid conditions (aRR: 2.99, 95\% CI: 1.09, 8.21, $\mathrm{P}=0.034$ ), higher CRP levels (aRR: 1.02, 95\% CI: 1.01, 1.03, P = 0.044), and lower lymphocyte (aRR: $0.82,95 \%$ CI: $0.73,0.93, \mathrm{P}=0.003$ ) were associated with increased risk of death.

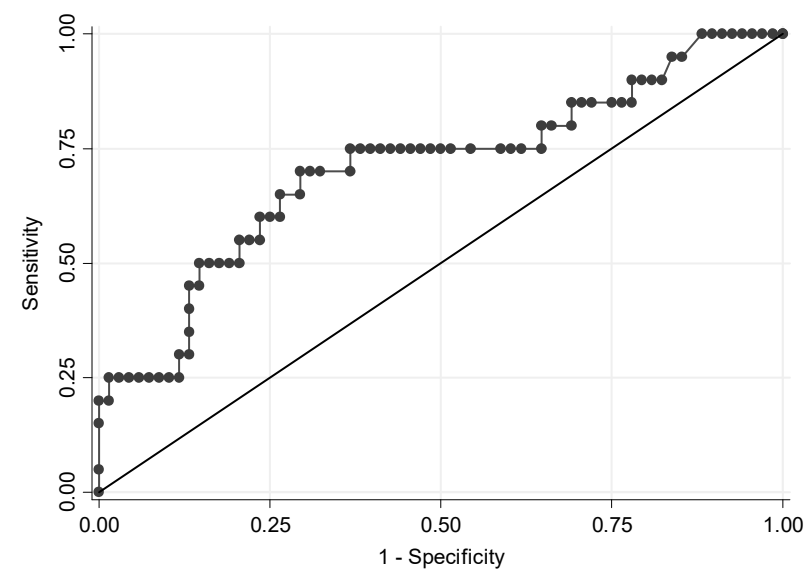

A

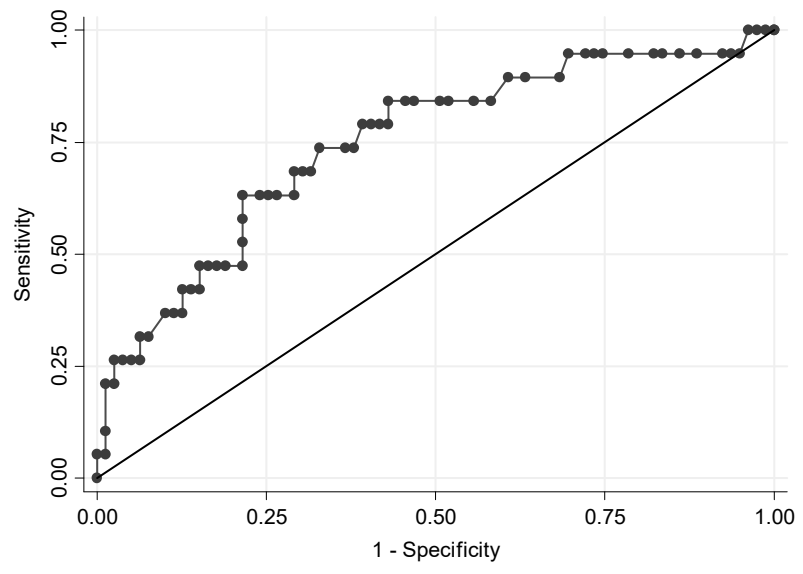

B

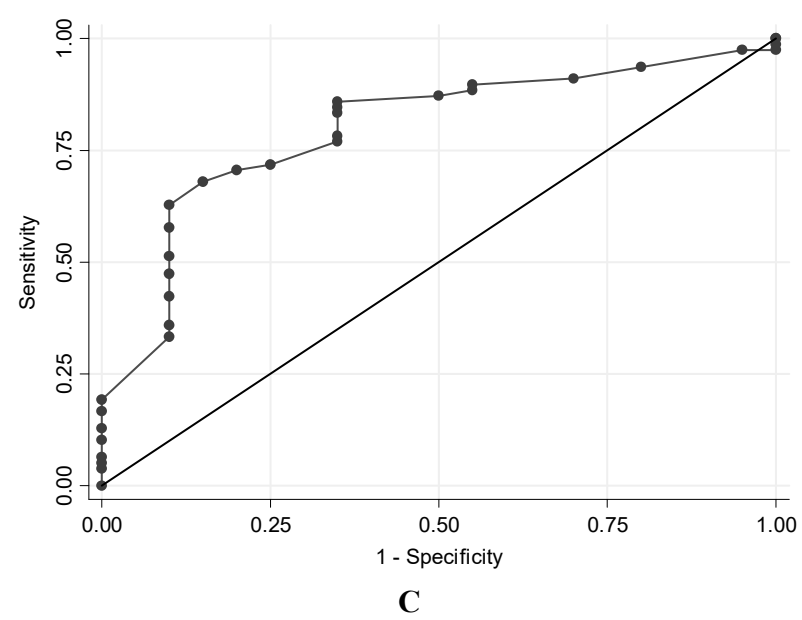

Figure 1. Receiver operating characteristics curves of (A) C-reactive protein, (B) white blood cell, and (C) Lymphocyte in the prediction of in-hospital death. 
All patients received antiviral treatment, including a single $400 \mathrm{mg}$ oral dose of hydroxychloroquine sulfate, or a single $500 \mathrm{mg}$ oral dose of chloroquine phosphate along with Kaletra (lopinavir/ritonavir) two $200 \mathrm{mg}$ tablets BID, for 5-14 days. Moreover, cephalosporins and glycopeptide antibiotics have also been used for some patients with suspected staphylococcal infections.

\section{DISCUSSION}

COVID-19 is mainly transmitted through respiratory droplets and also close contact with infected cases, and the studies into the viability of the virus outside the body have not yielded any accurate results [12]. The clinical course of COVID-19 was characterized by fever, mostly dry cough, and the development of gradual dyspnea in some cases and also ARDS in severe patients [13].

The current retrospective cohort study identified some risk factors for death in 100 adult cases who were admitted to the hospitals affiliated to Babol University of Medical Sciences with COVID-19 for the first time. In particular, older age, underlying diseases, elevated levels of CRP, WBCs and lymphopenia on admission were associated with higher odds of death in the hospital.

In agreement with the results of our study, other researchers showed that sex may not be an influencing factor of disease-related mortality of COVID-19. These results differ from some other reports that showed COVID-19 is more likely to affect males [14].

Advanced age was a risk factor for viral infection and poor prognosis. Our data suggested that deceased patients were older than survived cases. In agreement with our study Wang et al. suggested that age and comorbidity can be risk factors for poor outcomes [12]. The possible reason for the association between infection-related mortality, particularly viral infections with age, may be due to impaired cellular immune function and a longer duration of inflammation in the elderly [15].

As reported in previous studies, patients who have a history of coexisting conditions as hypertension, diabetes, cardiovascular disease and malignancies are at higher risk of COVID-19 infection [16]. Recent studies revealed that the majority of coronavirus cases were patients with chronic diseases, which indicated that these patients might also be at increased risk of becoming critically ill or death [17]. Our study showed that non-survivors were significantly more likely to have underlying diseases, including hypertension, cardiovascular disease, chronic kidney disease, and COPD.
Our research showed that lymphopenia occurred in many patients particularly non-survivors, which is a key laboratory feature in COVID-19 cases. Studies reported that more than $80 \%$ of critically ill patients with COVID-19 showed lymphopenia [18]. It is important to note lymphopenia as a trace of severe COVID-19 was confirmed by some researchers who revealed that deceased cases exhibiting significant lymphopenia. Studies revealed that endothelial dysfunction following chronic conditions induces some defects as endothelial cell death, enhanced leukocyte extravasation, and blood-tissue barrier disruption which might contribute to describe the lymphopenia detected in severe COVID-19 cases [19].

We also found that elevated initial CRP was a factor associated with death in COVID-19 patients. Our study reported that CRP levels of $>64.8 \mathrm{mg} / \mathrm{dl}$ associated with in-hospital death, sensitivity and specificity of $70.05 \%$ and $70.59 \%$, respectively.

As studies have shown CRP is one of the most sensitive acute-phase reactants and is almost absent in healthy individuals. CRP levels can increase after viral and bacterial infections, and inflammations [20]. CRP is an important marker of inflammation but lacks the required specificity for differentiation between bacterial and viral infections. Our laboratory results showed that the WBCs and CRP levels were elevated in non-survivors and the lymphocytes were decreased.

Based on these results it can be suggested that severe pneumonia in COVID-19 may be accompanying bacterial infection and also immune deficiency in the elderly may be an influencing factor for poor prognosis in these cases [21]. Therefore, elevated CRP and WBCs level along with lymphopenia reflects their role in the pathogenesis of COVID-19 and also particularly CRP and lymphopenia may serve as an important predictor of COVID-19 mortality.

Our study has some limitations. First, due to the critical condition caused by this infection, the sample size of the report has decreased at this point. Therefore, it is advisable to use more sample sizes in subsequent studies to more accurately assess the association between variables. Second, due to the retrospective study design, not all laboratory tests were done in all patients.

\section{CONCLUSION}

Most non-survivors were older patients with comorbidities (especially hypertension, cardiovascular disease, chronic kidney disease, and COPD). 
Gradually decreased lymphocytes and increased WBCs along with inflammation biomarkers as CRP were associated with increased risk of death. Thus, it is suggested that clinicians evaluate these factors in the initial diagnosis of this infection and also during the treatment of the infection.

Introducere. În decembrie 2019 in China a apărut o epidemie cu noul coronavirus (COVID-19), patologie ce s-a răspândit pe toate continentele. Scopul studiului a fost de a evalua caracteristicile clinice şi paraclinice ale infecţiei cu noul virus.

Materiale şi metode. A fost realizat un studiu retrospectiv pe 100 de pacienți cu COVID-19. Pacienţii au fost internaţi in spitalele afiliate Universităţii din Babol din 25 februarie 2020 până pe 12 martie 2020.

Rezultate. 19 pacienţi au decedat şi 81 au fost externaţi. Pacienţii nonsupravieţuitori au avut niveluri mai mari ale proteinei $C$ reactive-CRP (MD: 46,37, 95\% CI: 20,84, 71,90; $P=0,001$ ), leucocitoza (MD: 3,10, 95\% CI: 1,53, 4,67; $P<0,001)$ şi limfocite mai puţine (MD: $-8,75,95 \%$ CI: $-12,62,-4,87$; $P<0,001)$. Comorbidităţile aRR: 2,99, 95\% CI: 1,09, 8,21, $P=0,034)$, niveluri crescute ale CRP (aRR: 1,02, 95\% CI: 1,01, 1,03, $P=0$,044) şi prezenţa limfopeniei (aRR: 0,82, 95\% CI: 0,73, 0,93, $P=0,003$ ) s-au asociat cu riscul de deces.

Concluzii. Prezenţa comorbidităţilor, a limfopeniei şi niveluri mai mari ale CRP s-au asociat cu un risc mai mare a mortalităţii. Aşadar aceşti biomarkeri sunt de analizat în timpul tratamentului pacienţilor cu COVID-19.

Correspondence to: Soheil Ebrahimpour, Infectious Diseases and Tropical Medicine Research Center, Health Research Institute, Babol University of Medical Sciences, Babol, I.R. Iran.

Email: drsoheil1503@yahoo.com.

Tel: +989111149309. Fax: +981132207918

Acknowledgements: All of the authors wish to thank all the staff of Babol University of Medical Sciences affiliated hospitals.

Conflict of interest disclosure: All authors declare no conflict of interest.

\section{REFERENCES}

1. ZHOU P, YANG X-L, WANG X-G, HU B, ZHANG L, ZHANG W, et al. A pneumonia outbreak associated with a new coronavirus of probable bat origin. Nature. 2020; 579:270-3

2. LAI C-C, SHIH T-P, KO W-C, TANG H-J, HSUEH P-R. Severe acute respiratory syndrome coronavirus 2 (SARS-CoV-2) and corona virus disease-2019 (COVID-19): the epidemic and the challenges. Intern J antimicrob agents. 2020; 55:105924.

3. ORGANIZATION WH. Coronavirus disease 2019 (COVID-19): situation report, 71. 2020.

4. WU Z, MCGOOGAN JM. Characteristics of and important lessons from the coronavirus disease 2019 (COVID-19) outbreak in China. Jama. 2020.

5. AI T, YANG Z, HOU H, ZHAN C, CHEN C, LV W, et al. Correlation of chest CT and RT-PCR testing in coronavirus disease 2019 (COVID-19) in China: a report of 1014 cases. Radiology. 2020:200642.

6. GUO Y-R, CAO Q-D, HONG Z-S, TAN Y-Y, CHEN S-D, JIN H-J, et al. The origin, transmission and clinical therapies on coronavirus disease 2019 (COVID-19) outbreak - an update on the status. Military Med Res. 2020; 7:11.

7. LI Y, XIA L. Coronavirus Disease 2019 (COVID-19): Role of chest CT in diagnosis and management. Am J Roentgenol. 2020:1-7.

8. CHANG R, SUN W-Z. Repositioning Chloroquine as Ideal Antiviral Prophylactic against COVID-19-Time is Now. Preprints. 2020: 2020030279.

9. DHAMA K, SHARUN K, TIWARI R, SIRCAR S, BHAT S, MALIK YS, et al. Coronavirus Disease 2019-COVID-19. Preprints. 2020: 2020030001.

10. ADHIKARI SP, MENG S, WU Y-J, MAO Y-P, YE R-X, WANG Q-Z, et al. Epidemiology, causes, clinical manifestation and diagnosis, prevention and control of coronavirus disease (COVID-19) during the early outbreak period: a scoping review. Infect Dis Poverty. 2020; 9:1-12.

11. HUANG C, WANG Y, LI X, REN L, ZHAO J, HU Y, et al. Clinical features of patients infected with 2019 novel coronavirus in Wuhan, China. The Lancet. 2020; 395:497-506.

12. WANG D, HU B, HU C, ZHU F, LIU X, ZHANG J, et al. Clinical characteristics of 138 hospitalized patients with 2019 novel coronavirus-infected pneumonia in Wuhan, China. Jama. 2020; 11:1061-69. 
13. LI T. Diagnosis and clinical management of severe acute respiratory syndrome Coronavirus 2 (SARS-CoV-2) infection: an operational recommendation of Peking Union Medical College Hospital (V2. 0) Working Group of 2019 Novel Coronavirus, Peking Union Medical College Hospital. Emerg Microb Infect. 2020; 9:582-5.

14. CHEN N, ZHOU M, DONG X, QU J, GONG F, HAN Y, et al. Epidemiological and clinical characteristics of 99 cases of 2019 novel coronavirus pneumonia in Wuhan, China: a descriptive study. The Lancet. 2020; 395:507-13.

15. ZHOU F, YU T, DU R, FAN G, LIU Y, LIU Z, et al. Clinical course and risk factors for mortality of adult inpatients with COVID-19 in Wuhan, China: a retrospective cohort study. The Lancet. 2020; 395:1054-1062.

16. RUAN Q, YANG K, WANG W, JIANG L, SONG J. Clinical predictors of mortality due to COVID-19 based on an analysis of data of 150 patients from Wuhan, China. Intensive Care Medicine. 2020:1-3.

17. Yang J, Zheng Y, Gou X, Pu K, Chen Z, Guo Q, et al. Prevalence of comorbidities in the novel Wuhan coronavirus (COVID-19) infection: a systematic review and meta-analysis. Intern J Infect Dis. 2020:1-13.

18. YANG X, YU Y, XU J, SHU H, LIU H, WU Y, et al. Clinical course and outcomes of critically ill patients with SARS-CoV-2 pneumonia in Wuhan, China: a single-centered, retrospective, observational study. The Lancet Respiratory Medicine. 2020.

19. BERMEJO-MARTIN JF, ALMANSA R, MENÉNDEZ R, MENDEZ R, KELVIN DJ, TORRES A. Lymphopenic community acquired pneumonia as signature of severe COVID-19 infection: Lymphopenia in severe COVID-19 infection. J Infect. 2020.

20. SPROSTON NR, ASHWORTH JJ. Role of C-Reactive Protein at Sites of Inflammation and Infection. Front Immunol. 2018; 9:754.

21. LI J, LI S, CAI Y, LIU Q, LI X, ZENG Z, et al. Epidemiological and Clinical Characteristics of 17 Hospitalized Patients with 2019 Novel Coronavirus Infections Outside Wuhan, China. medRxiv. 2020.

Received $6^{\text {th }}$ April 2020 